\title{
The Swiss-ification of Ethnic Conflict
}

\author{
Historical Lessons in Nation-Building from the Swiss Example
}

\author{
Alexandre S. Wilner, Dalhousie University \\ Department of Political Science, PhD Candidate
}

\begin{abstract}
:
No modern nation-state has had as stable an historical legacy as that of Switzerland. In a world of explosive national and international discord, of recurring genocidal hatred, of chronic violence and ethno-cultural war, the Swiss example offers a light onto others, a veritable living political manuscript, outlining the historical methods that allow for the construction of highly stable and functioning multi-ethnic nation-states. Unlocking the Swiss case, then, provides us with the theoretical keys that will be necessary for avoiding "the coming anarchy" of the post-Cold War Era. The essay presents both an exploration of the historical development of Swiss nationalism and an evaluation of whether or not the Swiss example of post-primordial civic nationalism can act as an ideal model for others in Eastern Europe, Asia, the Middle East, and Africa. From the historical dialogue, three primary circumstances have guided the development of a stable national foundation in Switzerland; (1) the threat of an external 'alien other', (2) elite accommodation and consociation of the national project, and (3) an innate willingness and desire to behave and be governed as a unitary, yet multi-ethnic, nation. The conclusions suggest that while the Swiss case is necessarily an end-result of unique historical happenstance, the variables of stability are nevertheless universal and can be replicated by others living in distinct historical eras and geographical proximities. The lessons are of great value, then, to modern nationbuilding projects in Iraq, Sri Lanka, Israel/Palestine, Kashmir, Ireland/England, Spain and even, in Canada.
\end{abstract}




\section{Why Switzerland?}

Imagine, if you will, a modern state of seven million inhabitants of such heterogeneous complexity that even the dominant linguistic group does not represent, on its own, a majority of the voting populace. Imagine a state that is divided, unequally, into four distinctive language groups - each corresponding to a unique ethnic and cultural lineage with deep geo-historical roots - and then divide that state further into two separate and historically antagonistic religious camps. The image you may have constructed for yourself is of a society so deeply plagued by innate cleavages as to be utterly ungovernable by even the most brutal of authoritarian regimes. The result to befall such a state, you might rightly assume, must surely rest with the likes of a Yugoslavian, Rwandan, Iraqi, or Cypriot, outcome: irreconcilable differences will amount to great social animosities, disillusionment with the governing body, hardened irredentist aspirations, and perhaps, to occasional homicidal and genocidal attitudes. Surely, a state of such innate division could not function properly within its own borders, let alone internationally in the competitive capitalist system of the global economy. In fact, if you were later enlightened by an informed colleague that such a state did indeed exist, in a highly stable, secure, and functioning manner, you might, with sceptical assurance, ask to review your friend's academic sources. And yet such a national anomaly does indeed exit in the nation-state of Switzerland.

"Why Switzerland?" Indeed, in its short and abbreviated totality, Jonathan Steinberg's opening question represents perhaps the most quintessential starting point for an academic investigation into the many colourful paradoxes that underlie the history of Swiss nationalism. ${ }^{1}$ Switzerland - both as a prosperous European state and as a distinct case study analysis of nationalism and multinational states - does not immediately strike the reader as either a very interesting or seemingly important area for scholastic investigation. Simply stated, an evaluation

\footnotetext{
${ }^{1}$ Jonathan Steinberg, Why Switzerland? (Cambridge University Press, 1976), 1.
} 
of Swiss nationalism, unlike the many turbulent and emotional national representations that dot the political globe - the Kurds of the Persian Gulf, the Armenians of South-western Europe, the Tartars of the Crimea, the Chechnians of the Caucasus, the Palestinians of the Middle East, the Hutus of Central Africa, the Jews of Eastern Europe, to name but a few - is easily perceived as a rather dry, and even perhaps boring, academic enterprise. Switzerland as a nation-state, and its nationalistic sentiment by association, is stable in its construction, secure in its image, and confident in its fecundity. Even the recent re-emergence of ethnically and linguistically-based national sentiments (along with the political insecurities these sentiments have catalyzed) in seemingly stable Western states - Quebec nationalism in Canada, Catalonian and Basque nationalism in Spain, Walloon nationalism in Belgium, Irish nationalism in England - does not have its equivalent in the Swiss case. As such, Switzerland continues to exist as a stable national ideal; an island of calm and healthy multi-ethnicity in a sea of increasingly turbulent and oftentimes violent sub-state national aspirations.

Yet, like its multi-ethnic democratic cousins of Western Europe and North America, Switzerland itself remains a deeply and irrevocably cleavaged society. The Swiss paradox, then, of multi-ethnic national stability, represents an interesting anomaly for students of history, political science, and federalism. In Nationalism and Liberty: The Swiss Example, Hans Kohn, the great scholar and theoretician of national formation, devotes an entire manuscript to the evaluation (and ultimate praise) of Swiss nationalism, citing that "though Switzerland is only a small country of very limited natural resources, its kind of nationalism makes it an object of great and general interest at a period when the age of nationalism seems to reach its threatening 
climax in so many part of the globe" - a note that continues to have as great a resonances today as it did when Kohn first penned it in $1956 .^{2}$

In a world of explosive national and international discord, of recurring genocidal hatred, of chronic violence and ethno-cultural war, the Swiss example offers a light onto others, a veritable living political manuscript, outlining the historical methods that allow for the construction of highly stable and functioning multi-ethnic nation-states. Unlocking the Swiss case, then, provides us with the theoretical keys that will be necessary for avoiding "the coming anarchy" of the post-Cold War Era, and might, a most noble endeavour, help academic and policy decision-maker alike establish and promote stable multi-ethnic national cooperation in the $21^{\text {st }}$ Century. ${ }^{3}$

To begin, we need to explore, and perhaps answer, a few questions. How is it possible, for instance, that Switzerland has managed to escape the painful historical outcome so common to other multi-ethnic states? In that respect, what is unique about Swiss national identity that has allowed the various groups to accept, and indeed promote, the cultural and linguistic rights of the others, while retaining a common national identity? And perhaps most importantly, can the model upon which the Swiss national identity rests, be copied and emulated by other less-stable nation-states, or is it rather an historical anomaly of improbable repetition?

The purpose of this historical analysis, then, is twofold; first, to explore the historical development of Swiss nationalism and explain the circumstances that has allowed it to be embodied into a stable and secure state, and second, to evaluate whether the Swiss example of post-primordial civic nationalism can act as an ideal model for others in Eastern Europe, Asia, the Middle East, and Africa to follow. The conclusions drawn from the Swiss example are

\footnotetext{
${ }^{2}$ Hans Kohn, Nationalism and Liberty: The Swiss Example (Ruskin House, 1956), 8.

${ }^{3}$ See Robert D. Kaplan, The Coming Anarchy: Shattering the Dreams of the Post Cold War (Vintage Books, 2000).
} 
themselves also twofold in nature. Firstly, while the Swiss case is necessarily an end-result of various unique historical occurrences (as every national endeavour must), the variables that have led to a stable and inclusive Swiss nation are nevertheless common enough so as to be replicable by others. Secondly, as a post-modern and post-primordial model of nationhood, the Swiss model of nation-building and statecraft is indeed the finest example and ideal model for the establishment of other stable and functioning multi-ethnic, multi-linguistic, and multi-religious nation-states, secure in their diverging identities and deeply confident in their national foundation.

The argument is presented in three sections. Part one of the paper will offer a brief historical overview of Switzerland, introducing the Swiss people, their state, and the specific cultural and linguistic cleavages that mark their nation. Part two will then present three primary circumstances that have led to the development of a stable national foundation in Switzerland: (1) the threat of an external 'alien other', (2) elite accommodation and consociation of the national project, and (3) an innate willingness and desire to behave and be governed as a unitary, yet multi-ethnic, nation. By way of concluding the argument, section three will suggest that while the Swiss case is necessarily an end-result of unique historical occurrences, these stabilizing variables are nevertheless common enough, geographically and politically, so as to be of use by others living in distinct historical eras and geographical proximities. The lessons are of great value, then, to modern nation-building projects in Iraq, Sri Lanka, Israel/Palestine, Kashmir, Ireland/England, Spain and even, in Canada.

\section{From Confederation to Federation: A Union of Halberds}

The Swiss date the beginning of their nation-building project to the Middle Ages, with the formation, in 1291, of a Swiss Confederation between the Cantons of Uri, Schwyz, and 
Unterwalden (each of them German-speaking) ${ }^{4}$ More than anything, the Swiss league of feudal mini-states was a military alliance, established to deter the aggressive expansionist sentiments of Rudolf of Habsburg, the new King of Germany, and in so doing, preserve, according to Kohn, "the independence of the individual and fully sovereign member states." ${ }^{5}$ Yet the Treaty of 1291 was quite different from the many other military leagues of the day. A central feature of the pact, a parchment of which still exists today, cites that the parties of the treaty agreed "in common council [and] with one voice... [to] accept no judge nor recognise him in any way if he exercises his office for any reward or for money or if he is not one of our own and an inhabitant of the valleys [of Uri, Schwyz, and Unterwalden]. ${ }^{.6}$ Unquestionably, the Treaty of 1291 introduced the idea of a nascent Swiss union, or nation, evident both in the name union members adopted for themselves, Eidgenossen (comrades of the oath). Eidgenossenschaft, incidentally, is today the Swiss-German word for the Federal Union and a close German synonym for 'Swiss' - and in the rejection of any imposed alien social or political order. ${ }^{7}$ The Confederation fared rather well against enemy kingdoms, its inhabitants a hardy and Spartan-like bunch. Success in war brought with it an expansion of the union to include various other mountain communities, free states, and peasant Cantons, including, Lucerne (1332), Zurich (1351, Glarus (1352), Zug (1352), and Bern (1353), each of which accepted the terms of political equality set out by the 1291 agreement. ${ }^{8}$ By the sixteenth century, the Swiss Confederation swelled to thirteen members, and had become a

\footnotetext{
${ }^{4}$ Nicholas Gillett, The Swiss Constitution: Can it be Exported? (YES Publications, 1989), 12. The treaty, incidentally, was signed in Central Switzerland at Rütli Meadow. It was at this same meadow were General Henri Guisan, the Commander of the Swiss Army, summoned, in response to overwhelming Fascist military victories in Europe, 600 of his highest officers in July of 1940 to prepare them for the coming years of war. "The survival of Switzerland is at stake" he proclaimed. The symbolic importance of the meadow is reaffirmation of the strength and will of the Swiss nation to defend itself from external enemy attack. See Stephen P. Halbrook, Target Switzerland: Swiss Armed Neutrality in World War II (Sarpedon, 1998), 1-3.

${ }^{5}$ Kohn, op. cit., 18.

${ }^{6}$ Quoted in Steinberg, op. cit., 13.

${ }^{7}$ Ibid., 14-15. So central is the signing of the 1291 Treaty to Swiss national identity, that the date of its signature, "incipiente mense Augusto 1291" is annually celebrated on August 1 as Switzerland's National Day. William E Rappard. Collective Security in Swiss Experience: 1291-1948 (Bradford \& Dickens, 1948), 4.

${ }^{8}$ Ibid., 16.
} 
well-respected European military power. Switzerland's military prowess was epitomized by the Swiss weapon of choice, the Halberd, a nasty, spiked axe-blade fashioned onto a six-foot spear, which, incidentally, is still brandished today by the Swiss Guards of the Vatican City. ${ }^{9}$ And yet, Kohn adds, the Swiss Confederation "was not strong enough to support a great power policy of warfare and expansion...too weak to support an active warlike policy," in Europe, and preferred, rather, to protect their "own way of life, which they regarded as their freedom," to the lures of greater European political power. ${ }^{10}$

The Confederation's refusal, in the seventeenth century, to follow the emerging trend of the rising 'power-states' - quite contrary to the tenets of realist International Relations thought and its rejection of a centralized authority (which would have conceivably allowed the Swiss to participate in international armed conflict), forced the nascent state into a policy of neutrality - a policy that continues to survive nearly six hundred years later. Unbeknownst to the leaders of the time, the adoption of armed neutrality would later preserve the unity of Switzerland in the tumultuous years of the Reformation and the decades of Religious Warfare that followed. Reformation split Switzerland into two antagonistic religious camps (Catholicism and Protestantism), and international neutrality proved the only policy that would allow for Swiss unity and sovereign independence. ${ }^{11}$ In fact, as the rest of Europe buckled in response to decades of bitter religious warfare, the two faiths were treated as domestically equal, regardless of their domestic strengths, within the tranquil island of the Swiss union.

With the coming of the Enlightenment in the eighteenth century and the resulting shift away from the religious fervour that had gripped Europe for over a century, a new sense of national patriotism swept through Switzerland. Among enlightened intellectuals, a growth in the

\footnotetext{
${ }^{9}$ Steinberg, op. cit., 15.

${ }^{10}$ Kohn, op. cit., 20-21.

${ }^{11}$ Ibid., 21.
} 
'feeling' of Swiss unity began to emerge, which stressed not the centuries of military cooperation and alliance as a unifying force, but rather the common memories of historical liberty and democratic values the cantons continued to share. ${ }^{12}$ The era of Enlightenment, writes Steinberg, allowed for the emergence in Switzerland of what he calls, "the ideology of democracy."13 Under this backdrop, a serious attempt was made, by both inspired intellectuals and pragmatic political leaders, to solidify within the Swiss national psyche, various historical myths. Ancient stories of ordinary Swiss yeomen and burghers uprising against the tyranny of the aristocrat and of Swiss farmers uniting in battle against the knights and lords of Europe became popular. Perhaps most fundamental, the mythical story of William Tell - whose soldiery defiance of the Habsburgs and skill and courage as a bowman allowed him to shoot an apple off the head of his son and thwart the plans of the conquering Germans - became the 'communal tradition' and national ideal that allowed the Swiss to define, mark, and fortify their public values into a unified national sentiment. ${ }^{14}$ The story of Tell - and what his actions represented - became the 'Swiss-ness' of the fledging nation. ${ }^{15}$ Thus, by the end of the eighteenth century, a new spirit of Swiss national identity rooted itself to these historical national memories and became the foundational platform upon which modern Swiss identity would anchor itself in the subsequent centuries.

The French Revolution and Napoleon's 1798 invasion of Switzerland marked the end of the ancient Confederation and the beginning of a new Swiss nation-state. Yet, while the newlyforming ethnic nations of Western and Eastern Europe (Germany, Italy, and Poland) rejected the ideals of the French Revolution for a more primordial image of themselves, the Swiss reaction to

\footnotetext{
${ }^{12}$ Kohn, op. cit., 26.

${ }^{13}$ Steinberg, op. cit., 18.

${ }^{14}$ For a rather comical and thorough evaluation of William Tell's myth, see Fritz Ernst, European Switzerland (Fretz \& Wasmuth Limited, 1951), 45-50.

${ }^{15}$ Kohn writes that the new "Rousseauan enthusiasm" of the eighteenth century glorified Tell not only "as a patriotic hero" of Switzerland, but also "as a fighter for human rights against tyranny." Kohn, op. cit., 24-25 (Italics Added).
} 
1789 was different; they accepted and absorbed the lessons of the Revolution and fused them to their pre-existing and ancient ideals of liberty and freedom. Kohn writes that while the Swiss Confederation "ignominiously died" in 1798 after five hundred years of independent existence, "the ancient foundations of liberty, the humanist traditions, and the enduring influence of Napoleon's reforms, allowed the Swiss...to rebuild their nation as a strong, modern democracy, which achieved, to a degree unknown to its neighbours, liberty under law and unity in diversity." ${ }^{.16}$ Under Napoleonic rule, the Confederation was dismantled and a new Swiss entity, the Helvetic Republic (1803) was established. The Swiss Republic, a federation of thirteen cantons, was enshrined in a new Swiss Constitution, based on the conceptions of the Enlightenment and the rights and freedoms of man. Overnight, the new Constitution, rooted to the French ideals of state centralization and authoritarian executive power, transformed Switzerland from a loosely-aligned Confederation of independent polities into a modern federalist state. The 1803 Constitution abolished all pre-existing social privileges, established the legal equality of individuals and territory, accepted Italian as the third official national language, provided for national coins and stamps (printed in Latin lest to offend any one national linguistic group!), and, for the first time, created a centralized parliamentary system that represented, in function and political practice, the Swiss nation. ${ }^{17}$

And yet the centralized powers of the new Swiss government proved too overbearing for the multi-ethnic nation. With Napoleon's downfall, a new Swiss Constitution was written in 1815. Its foundation, rooted to the previous Constitution, nevertheless regressed Switzerland towards the decentralized consociation of sovereign cantons that had existed before Napoleon, replaced the parliament with a Diet, and allowed for the accession of various non-German

\footnotetext{
${ }^{16}$ Ibid., 34. (Italics added).

${ }^{17}$ Carol L Schmid, Conflict and Consensus in Switzerland (University of California Press, 1981), 3-4.
} 
Cantons (Valais, Neuchatel, and Geneva) into the Confederation. Yet if the 1805 Constitution was too centralized, the 1815 Constitution itself proved to be too de-centralized. By 1846 , divisions between the Cantons, along Liberal-Revisionist lines emerged, and the Swiss Civil War (the Sonderbund - 'separatist confederation' - War) erupted the following year. Short-lived, the Sonderbund War lasted 25 days with the loss of only 128 men on either side. ${ }^{18}$ Finding a compromise between the excesses of the Federation and the deficiencies of the Confederation, the liberal victors established a third and final Constitution in 1848. It established two political institutions; the Standerat, (The Council of States) created on the model of the old Confederation's Diet and on the United States Senate, which gave each canton two regional statesmen, and the Nationalrat, (The National Council) patterned after the American House of Representatives, in which canton representation was based on the proportionality of population. ${ }^{19}$ The 1848 Constitution, amended slightly in 1874 , established the proper political mechanisms and institutional balances that were needed to solidify the nascent Swiss nation and remedy the linguistic and ethnic differences that it encompassed. From that point on, a strongly unified Swiss nation prospered within a unified political federal system.

\section{The Modern Swiss: Unity in Diversity}

What does Switzerland look like today? Our historical overview mentioned, in passing, the existence of various minority groups coexisting throughout Switzerland's history. Generally speaking, the composition and diversity of these various ethnic groups continues today. The current population of Switzerland is approximately 7.3 million. Of that total, approximately 64 percent speak Swiss-German, 20 percent speak French, approximately 8 percent speak Italian, and less than 1 percent speaks Romansch (a recognized 'National Language', as of 1938, yet an

\footnotetext{
${ }^{18}$ Ibid., 6-7

${ }^{19}$ Ibid., 7-8
} 
'Un-official Language' with limited governmental use). Table One, below, draws these figures, and historical language divisions out schematically. While one can easily accept these figures in their entirety, that is, accept the general categorization of Switzerland into four linguistic groups, doing so significantly simplifies the actual linguistic situation 'on the ground'. For instance, all 'German' speakers are in fact bilingual, as Steinberg notes, in that "they speak a language they do not read or write ('Low' German (Schwyzerdutsch) of numerous dialects), and read and write in a language which they sometimes speak ['High' German, which they use in conversation with non-Swiss-Germans] but not as a mother-tongue. ${ }^{, 20}$ There are perhaps over 20 distinct dialects of Schwyzerdutsch currently spoken in Switzerland. Of the 60,000 Romansch-speakers, there are two literary dialects (both of which have their own written languages) and two non-literary dialects that can only be spoken. For their part, the Italian-Swiss speak three distinct dialects but share 'High' Italian - the Italian of Italy - as a literary-language. The French-Swiss are the only linguistic group that speak and write in one common dialect.

In terms of geographic divisions, it is important to note that linguistic groups often adhere to specific cantonial boundaries. Accordingly, of the 26 Cantons, 17 are officially Germanspeaking, 4 are French-speaking, 1 is Italian-speaking, while the remaining 4 are sufficiently linguistically divided to have two or three official languages. ${ }^{21}$ Confused? Consider this; travelling through Switzerland, a tourist would likely encounter a new language or dialect every 30 kilometres. The complexity of administering a functioning national government and productive economic system, let alone establishing one single and commonly-shared national identity, is simply bewildering.

\footnotetext{
${ }^{20}$ Steinberg, op. cit., 2

${ }^{21}$ Kenneth D McRae, Conflict and Compromise in Multilingual Societies: Switzerland (Wilfrid Laurier University Press, 1983), 42.
} 
Table One: Percentage of Swiss Citizens by Mother Tongue

\begin{tabular}{|r|r|r|r|r|r|}
\hline Consensus Yr. & German (\%) & French (\%) & Italian (\%) & Romansch (\%) \\
\hline $\mathbf{1 9 1 0}$ & 72.7 & 22.1 & 3.9 & 1.2 \\
\hline $\mathbf{1 9 5 0}$ & 74.1 & 20.6 & 4.0 & 1.1 \\
\hline $\mathbf{1 9 7 0}$ & 74.5 & 20.1 & 4.0 & 1.0 \\
\hline $\mathbf{2 0 0 4}^{*}$ & 63.7 & 19.2 & 7.6 & 0.6 \\
\hline
\end{tabular}

Source: Steinberg, Why Switzerland?

The linguistic divisions are really only part of the social complexity that exists in Switzerland. Since the Reformation, Swiss religious affiliation has been fairly evenly divided into Protestant and Catholic groups. The 2004 Consensus revealed that approximately 40 percent of Switzerland's citizenry considered themselves Protestant, 46 percent considered themselves Catholic, while the remaining 14 percent were neither of the two or consider themselves nonreligious. Table Two presents these figures. In recent decades, the Catholic group has swelled in number, partly due to higher birthrates but also because of a higher rate of entry of Catholic foreign workers (primarily from Italy) into Switzerland. The non-protestant/non-catholic group has also swelled since the 1970 s, partly because of a general turn towards secularism in urbanized areas, but also due to an influx of non-European workers who bring their own religious beliefs.

\footnotetext{
* Attentive readers will have noticed that the Linguistic Figures presented for 2004 are incomplete, in that they do not add up to 100 percent. The remaining linguistic group(s), are represented by none of the four official languages and constitute immigrant groups and foreign workers, of which 1.3 million currently work and live in Switzerland.
} 
Table Two: Percentage of Swiss Citizens by Religion

\begin{tabular}{|r|r|r|r|r|}
\hline Consensus Yr. & Protestant (\%) & Catholic (\%) & \multicolumn{2}{|l|}{ Other (\%) } \\
\hline $\mathbf{1 9 1 0}$ & 61.4 & 37.8 & 0.8 \\
\hline $\mathbf{1 9 5 0}$ & 58.5 & 40.3 & 1.2 \\
\hline $\mathbf{1 9 7 0}$ & 55.0 & 43.4 & 1.6 \\
\hline $\mathbf{2 0 0 4}$ & 40.0 & 46.1 & 13.9 \\
\hline
\end{tabular}

Source: Steinberg, Why Switzerland? and CIA Factbook.

And so, the image of modern Switzerland is of a mosaic of great linguistic, ethnic, and religious complexity. Yet amid the mess, there exists one "fortunate historical accident" - one of those rare and unexplainable chance developments - to Switzerland's geographical and social formation that has unconditionally assisted in calming inter-group relations. That is, linguistic and religious boundaries do not coincide. ${ }^{22}$ Members of each linguistic group practice both major religions (to a varying degree) in every canton, and hence religion actually acts to offset linguistic loyalties. Thus, in French-Switzerland, Protestant majorities exist in two French Cantons (Vaud and Neuchatel), while Geneva is evenly divided by the two faiths, and Valais and Fribourg (bilingual Cantons with French-majorities) have a strong Catholic majority. A similar set of circumstances exits in German-Switzerland, with the nine predominately Protestant Cantons of German-majority being offset by the seven predominately Catholic-German Cantons. Ticino, the only Italian-speaking Canton, is overwhelmingly Catholic, while the Romansch-areas

\footnotetext{
${ }^{22}$ Schmid, op. cit. , 7 .
} 
are divided into more-or-less equal religious sections. These "cross-cutting cleavages" have a very real effect of creating "cross-cutting pressures" among the Swiss population, which leaves no one linguistic or religious group with a strong-enough majority to singularly impose its will on the political process. ${ }^{23}$ And yet it would be naïve to accept, in toto, the cross-cutting thesis of Swiss stability. Historically, these divisions have not always existed as they do today, and certain historical periods, most notably during the years immediately before the onset of the First World War, have had their moments of language-based divisions. Andreas Wimmer explains that between 1914-1919, "for the first...time in Swiss history, political alliances became realigned on the basis of language," evident in the creation of the so-called (and short-lived) "Linguistic Trench" that pitted pro-Axis German-Swiss against neutral-oriented French-Swiss. ${ }^{24}$

Furthermore, the cross-cutting thesis, when applied to other case studies - most notably Canada and Belgium - fails to produce similar causal results, with linguistic divisions in these states having the opposite force of actually crystallising divisional public and political opinion based on language. ${ }^{25}$ In any event, for the purpose of this paper, it is simply enough to note that the many social divisions in Switzerland are both misleadingly compartmentalized (because of the existence of dozens of various German, Italian, and Romansch dialects) and difficult to understand because of the cross-cutting nature of religious practice.

\footnotetext{
${ }^{23}$ Ibid., 10, 22.

${ }^{24}$ Andreas Wimmer, Nationalist Exclusion and Ethnic conflict: Shadows of Modernity (Cambridge University Press, 2002), 236. A similar, albeit less powerful linguistic division also developed in 1939 at the onset of the Second World War, with Swiss-Germans sympathizing with Germany and French-Switzerland sympathizing with France. However, unlike the previous linguistic trench, this one was extremely short-lived and generally not popular. With Germany's invasion of Belgium, any Swiss-German loyalty to the Axis evaporated completely, as the Central Powers were, according to Stephen P. Halbrook, "seen more and more to represent anti-democratic forces contrary to the Swiss tradition of individual liberty and democratic government." See Halbrook, op. cit., 20.

${ }^{25}$ For further discussion, see Henry H. Kerr, Jr. Switzerland: Social Cleavages and Partisan Conflict (Sage Publications, 1974), 5-8.
} 


\section{Establishing a Multi-Ethnic Nation: How the Swiss did it}

We turn now to a more theoretical evaluation and explanation for the existence of a stable multi-ethnic Swiss national identity. While theorists of nationalism have developed several theoretical rationales for Swiss stability (the abovementioned 'cross-cutting cleavages' thesis is but one such example), I have identified three other circumstances, or factors, that have helped in the formation of a stable Swiss identity; (1) the presence of an overbearing external military threat, (2) elite accommodation and guidance, and (3) an innate will among the various groups to cooperate, cohabitate, and participate in nation-building. Each will be explored below in detail.

\section{External Threats: Rallying Around the Flag of Swiss Ideals}

Switzerland's history began, it was mentioned, as a response to the threat of war and invasion of the free Cantons by external enemies and the formation of various alliances and collective security measures against these threats. Both the ancient Swiss Confederation and the modern Swiss Federation are embodiments of such calculations. William E. Rappard's book, titled Collective Security in Swiss Experience: 1291-1948, represents the most thorough evaluation and ultimate support of the 'external threat' thesis of Swiss national formation. His argument, widely supported by others, ${ }^{26}$ rests on the assumptions that the threat of territorial invasion by a "common hereditary enemy", along with the consequent elimination of both political autonomy and political freedom such incursions would result, forced the tiny cantons into military agreement. The process of alliance formation necessarily solidified a set of commonly-shared values - of freedom, liberty, democracy, self-government, and independence -

\footnotetext{
${ }^{26}$ Fritz Ernst, for instance, writes: "However highly we esteem the autonomous powers within Switzerland, one reason...for the origin and continuance of the Swiss Republic, has been the historic rivalry between the Great Powers." See Ernst, op. cit., 69. (Italics added). Kohn also supports this thesis, writing: [The Swiss Confederation's] ties consisted in the recognition of the need for common military action in case of outside aggression and in the feeling of a similar love of liberty and reliance on self-government. Slowly their co-operation in defence of their independence and liberties grew into a true federal union." Kohn, op. cit., 9.
} 
that became the embryonic foundation and common cultural belief-system of the future Swiss nation. "Switzerland," writes Rappard, "was thus born of the will to independence of external control," that throughout the centuries was further "unified by a continuous struggle for the consolidation and extension of this independence." 27 As a result, then, mutual threat of invasion and communal protection against the 'alien other', stressed - perhaps as an unintentional sideeffect - the common cognitive and social beliefs the differing ethnic and linguistic groups in Switzerland shared with one another. Carol L. Schmid adds that in Switzerland's case, "conflict contributed to the process of nation formation... [because] resistance to foreign powers creates nations by transforming a vague sense of ethnic difference into a crystallized sense of national identity." 28 Thus, the threat of external invasion, the continual focus on protecting territorial boundaries, and the opposition to 'enemies of the nation' all acted to shift Swiss attention towards a hardening of common national objectives and goals rather than on a focus of divisive trans-ethnic characteristics.

The establishment of a Swiss military force also further catalyzed cohesive national sentiment. For instance, the style, or perhaps type, of military structure the Swiss established and to a certain extent continue to practice today - was primarily based on the formation of a 'citizen's militia' rather than a standing Swiss army. The defence of the state was the duty of every Swiss man and women, regardless of ethnic creed. During the Cold War, for instance, Switzerland retained a military force 600,000 strong - over twice the size of neighbouring armies. While a major military reform initiative took place in 2003, the Swiss Constitution nevertheless obliges every Swiss male to do roughly a year's worth of military service over a twenty year period - nowhere in the Western world, save perhaps Israel, is such a national duty

\footnotetext{
${ }^{27}$ Rappard, op. cit., 5.

${ }^{28}$ Carol L Schmid, The Politics of Language: Conflict, Identity, and Cultural Pluralism in Comparative Perspective (Oxford University Press, 2001), 125-126.
} 
required. ${ }^{29}$ The affect of such a lengthy military service is simple. Every Swiss citizen is involved in the military, which necessarily creates a sense of common national identity. Of perhaps even greater interest is that fact that all enlisted men must keep his equipment at home (!) so that he can be immediately prepared to join one of the dozens of local militias in the event Switzerland is attacked or invaded. ${ }^{30}$ In essence, the militia-style defence and the all-inclusive duty to protect the state, united all ethnic groups to one central national purpose. "To attack the Swiss army" Steinberg concludes, "is to attack the Swiss state and the image of the armed free citizen on which it rests. To attack the army is to attack the status quo, for a militia stretches like a tight garment around the shape of the existing social order. To attack the army is to assail the very identity and self-image of the Swiss people." ${ }^{\prime 31}$ The threat of external invasion, forced the free peasants to arm themselves, and fight, in the name of state and nation, for the defence and autonomy of their community. It created, in the meantime, a national identity separate from ethnic creed that stressed the common values of political freedom and self-government.

\section{Elite Accommodation: Giving Nation-Building a Helping Hand}

Quite apart from the 'external threat' thesis explored above, the establishment, or perhaps creation, of a Swiss nation was also due to a concerted effort by various Swiss elites to form and support a common national identity. Elite accommodation, or consociation - understood as the formation of a specific political arrangement in which various ethnically divided groups share political power according to a mutually agreed-upon formula or institutional mechanism - was also an important precursor, and perhaps altogether necessary tool, for the formation of the Swiss nation. The consociational model of nation-building emphasises the vital importance of the

\footnotetext{
${ }^{29}$ Marc-Andre Miserez, "Debate heats up over Swiss Army System”, Swissinfo, August 5, 2004; $<$ http://www.swissinfo.org $>$, Accessed August 28, 2006

${ }^{30}$ Steinberg, op. cit., 165-167.

${ }^{31}$ Ibid., 164 (Italics Added).
} 
capacity and good will of leading elites to help solidify and nurture a common identity within an ethnically divided nation. Carol Schimd writes, citing Arend Lijphart's work on the consociation model of nationalism, that "overarching cooperation at the elite level with the deliberate aim of counteracting disintegrative tendencies in the system," is required because only "deliberate joint effort by the elites can stabilize the sharp cleavages" of a multi-ethnic society. ${ }^{32}$ As our historical analysis suggests, the rise of 'Swiss-ness' developed with the emergence among leading enlightened intellectuals in the eighteenth century of a commonly-perceived Swiss identity and an accepted will to cooperate, socially and politically, for its evolution. And hence, beginning in the mid-1700s, various Swiss scholars, elites, and philosophers sought to cooperate on a common national adventure.

Jean-Jacques Rousseau, a native of Geneva, wrote colourfully in 1763 , that the thirteen Cantons of Switzerland acted as "une grande ville, divisée en treize quartiers" (a great city, divided into thirteen quarters) in which all the inhabitants suffered from "le hemvé" or homesickness. ${ }^{33}$ The establishment, by German-speaking elites, of the Helvetic Society in 1797 (in association with the University of Basle) was a direct attempt by the organization's leaders to help re-awaken among the Swiss, a common awareness of their communal belonging. Many of the Society's members would later become leading political figures in the newly-formed National Legislature of the Hevetic Republic, formed, you will recall, with Napoleon's help in 1803. By mid-century, hundreds of these associations existed throughout Switzerland, nearly all of them cross-regional and multi-ethnic in scope and membership. In these newly established, multi-ethnic associations - such as The Swiss Association of Artists (1807), The Swiss Association of Pedagogy (1808), The Swiss Society for the Public Good (1810), the Swiss

\footnotetext{
${ }^{32}$ Schmid, Carol L. Conflict and Consensus in Switzerland (University of California Press, 1981), 12-13.

${ }^{33}$ Quoted in Kohn, op. cit., 26.
} 
Society for Historical Research (1811), the Swiss Society of Officers (1833) - German, French, and Italian elites began to build a patchwork of societal associations that created a social setting, or civil society, steeped in a distinctive Swiss identity. ${ }^{34}$ Other non-elite clubs, with much wider membership, also flourished during this period, with the Federal Association of Riflemen (1824) - an important precursor and training ground for militia-men - boasting nearly 2,000 members (of a total Swiss population of 2 million) only seven years later. ${ }^{35}$

All of these associations operated on a trans-cantonal basis, holding annual meetings in different parts of the country every year, and thus increased interregional travel. ${ }^{36}$ As a result, association to these elite groups allowed members to encounter the ethnic diversity of the Swiss nation while being introduced to the political commonalities and shared aspirations each ethnic elite held in common. The result was greater acceptance of ethnic and linguistic divisions, which helped suppress ethnic association while catalyzing and strengthening a common Swiss identity based on political commonalities rather than primordial differences. Over time, a thick network of civil society was created, which allowed for a trans-ethnic and inclusive forms of nationbuilding to take place, guided in certain respects, by ethnic elites who shared a common view of the future and a common interest in the successful development of the Swiss nation.

Indeed, even after Switzerland's inception as a nation-state, elite interests and consociation repeatedly helped stabilize ethnic relations. During both World Wars, tensions along ethnic lines were repeatedly dampened by elite foresight. For instance, in 1917, writes Wimmer, "the elite cartel from all ethno-linguistic groups...very quickly moved to an appeasement policy, trying to... realign political sentiments along the nationalist axis that they

\footnotetext{
${ }^{34}$ Wimmer, op. cit., 244-246.

${ }^{35}$ Ibid., 244.

${ }^{36}$ Ibid.
} 
had designed in previous decades. ${ }^{, 37}$ Similarity, in 1938, elite members of the Federal Council coined a new term - Geistige Landesverteidigung - "ideological national defence", in an attempt to clarify the political idea of Switzerland in order to reduce rising internal ethnic tension catalyzed by events occurring on the other side of the border. In so doing, elites re-affirmed the basis of the Swiss nation, as they had done during the formative years of the Confederation, and no doubt continue to do today. They stated, in unison; 'The Swiss national idea is not based upon race or biological factors, it rests on a spiritual decision. ${ }^{38}$ Without the support and guiding hand of elite association, it is likely that Switzerland's ethnic divisions would have been difficult to navigate and might have engulfed the state many decades ago.

\section{To Will a Nation to Life: An Innate Belief in the Nation-Building Project}

"A nation,” writes Ernest Renan, a leading theorist of nationalism, "presupposes a past; it is summarised, however, in the present by a tangible fact, namely, consent, the clearly expressed desire to continue a common life. ${ }^{, 39}$ Renan's emphasis on 'consent' and 'desire' represent a starting point for our third discussion regarding the development of a stable, multi-ethnic Swiss nation. Following his line of inquiry, any national project must depend, first and foremost, on a commonly-shared will, so that a nation is a group that wants to be treated as politically sovereign. ${ }^{40}$ Indeed, the Swiss have, for whatever historical, political, or geographical reason, a distinctive will, a desire, and a want, to behave and be governed as a unitary, and yet multiethnic, nation. Nothing, it might be assumed, could be more powerful than that, for the existence

\footnotetext{
${ }^{37}$ Ibid., 237.

${ }^{38}$ Kohn, op cit., 129.

${ }^{39}$ Ernst Renan, "What is a nation?" trans. Martin Thom, in Homi K. Bhabha (ed.), Nation and Narration (Routledge, 1990), 8-22.

${ }^{40}$ Ross Poole, Nation and Identity (Routledge, 1999), 35.
} 
of a national will is a necessary, but perhaps not sufficient, condition for the presence of a stable and functioning national identity.

The subject of a national will is quite abstract and unquantifiable, for how is one to find and explain such a feeling? And yet in the Swiss case, the invisible will of the Swiss nation is expressed on a daily basis. It is present in the fine balance the Swiss accept and practice, between their loyalties to a distinctive cantonal language and their allegiances to the inclusive attitudes of the collective federation. ${ }^{41}$ It is present, writes Kohn, in the "spirit of tolerance, restraint and good will towards minorities" that perforates Swiss society. ${ }^{42}$ And, it is present in the expectation and accepted belief, shared by every minority group, that the Swiss Constitution will continue to protect their interests and assist them in defending the integrity of their distinctiveness. ${ }^{43}$

In practice, the Swiss will is present in certain cultural traditions. It is significant, for instance, that when a French and German-Swiss speak together, regardless of whether they meet in a French or German Canton, the language to be used in conversation is most apt to be French. Likewise, when addressing a multilingual group, a Swiss-German will use High German, rather than his Low German dialect. These customs, explains Schmid, are practiced "as a convenience and courtesy to a minority language group." ${ }^{44}$ How very different from our customs in Canada, where a French-Canadian might be rather surprised to be addressed in French on the streets of Vancouver! Constitutionally, Swiss toleration is legally enshrined. Minority groups are overrepresented in the judiciary, the public service, and in federal organizations, and are generally granted a position of privilege, represented in government beyond their numerical

\footnotetext{
${ }^{41}$ Gillett, op. cit., 9.

${ }^{42}$ Kohn, op. cit., 115.

${ }^{43}$ Kenneth D. McRae, Switzerland: Example of Cultural Coexistence (Canadian Institute of International Affairs, 1964), 72.

${ }^{44}$ Schmid, op. cit., 31 .
} 
proportions. ${ }^{45}$ Administratively, linguistic territories are also recognized, so that a ticket collector, walking down the aisles of a train, will call for tickets in German until the 'invisible frontier' is crossed, at which time he will continue collecting them in French. ${ }^{46}$ Similarly, toleration and negotiation are taught in the education system. In the national teacher's handbook, a section is devoted to teaching Lebenskunde, translated as 'Information for Life', in which the importance of conflict mediation and resolution are stressed. In class, theories of mediation are taught and then applied to explain the outcome of various historical linguistic and cultural disputes that have developed in Switzerland. ${ }^{47}$ It would seem, then, that the Swiss nation, and the state that houses it, remains stable because of an historically based acceptance of the multi-ethnic national union and a continued belief in its need and value.

\section{Learning from the Swiss: Applying the Lessons of Switzerland's Nation-Building Project}

Our discussion so far has presented the Swiss nation as a rather unusual and curious political animal. In a world of seemingly chronic genocidal hatred and conflict - most, if not all, of it based on ethno-cultural and religious divisions - the Swiss example represents a case to be emulated. If you have followed my discussion to this point, you may have for yourself, begun to understand why the Swiss example, however unique, represents an important lesson in social and political cohabitation. Switzerland is a living expression of a set of ideas, steeped in toleration and acceptance that overshadow primordial divisions. It is an ideal. Steinberg paraphrases the lessons marking Switzerland's political experiment as such: "Although the will of the majority makes law and constitutes the only true sovereign authority, the minorities, however small, have

\footnotetext{
${ }^{45} \mathrm{Kohn}$, op. cit., 115.

${ }^{46}$ Schmid, op. cit., 32.

${ }^{47}$ Gillett, op. cit., 92.
} 
inalienable rights. The dilemma of majority will and minority rights can be overcome by the ingenuity of men." ${ }^{48}$ And yet our brilliant 'ingenuity' for solving our differences is rarely used.

I ask you then, to explain to me the differences that exist between Switzerland and Iraq; and Turkey; and Rwanda. Certainly, each state has developed along distinctive historical paths, and I am not so naïve to think that the various ethnic, cultural, linguistic, and cultural distinctions of these states matter little. Indeed they do and surely must. Yet, are the divisions that exist today between Kurd and Turk, Palestinian and Jew, Sunni and Shi'ite, so markedly different to those that once divided French Swiss and German Swiss, and Protestant and Catholic half a millennium ago? "There is no a priori reason," writes Wimmer, "why a separate nationalism for each of the linguistic regions [in Switzerland] sharing cultural features, common memories of historical struggles and so on, should not have developed." ${ }^{49}$ And yet these seemingly incompatible Swiss groups - indeed the very exact linguistic and religious groups that have been murdering each other for centuries across the Alpine border - decided to unite along a path of cohabitation and nation-building rather than succumb to the ruse of ethnic hatred. Do these ethno-linguistic cultural differences, then, in Iraq, Turkey, Rwanda, Yugoslavia and, to be sure, in Canada, Spain, and Belgium, explain or even warrant the less ideal political outcome that befell these nation-states as opposed to the near millennium of peace that developed in Switzerland?

"Switzerland," remarks André Siegfried, "is both the most national and the most international country in the world. ${ }^{, 50}$ In a world troubled by resurgence of the politics of ethnicity and a renewed brutal hatred of the 'other', our eyes should once again, as they did during the Wars of the Reformation, the Wars of Nationalism, and the World Wars of the

\footnotetext{
${ }^{48}$ Steinberg, op. cit., 188.

${ }^{49}$ Wimmer, op. cit., 225.

${ }^{50}$ André Siegfried, Switzerland: A Democratic Way of Life (Jonathan Cape, 1950), 177.
} 
twentieth century, turn towards Switzerland. "Because the Swiss are so different," writes Steinberg, "they serve as a mirror in which we see our own assumptions more clearly."51 Gazing into the mirror allows us to grasp the lessons afforded by the Swiss. They are as follows:

(1) The actual or perceived presence of an external threat to commonly shared interests can act to unite divergent neighbouring groups and can be tailored into a process of nationbuilding. The 'enemy' can be an actual opposing and external force (as in the case of the American Revolution which sufficed to unite French and English Canadians into a weak national union), an opposing yet internal force (as in current-day Iraq in which the presence of Western troops has catalyzed, according to some political pundits, the unification of historically antagonistic groups) $^{52}$ or an even less tangible external force (such as air pollution or global warming that threatens all groups equally). As a result of anarchic international relations, it is conceivable that all potential nations and nation-states have some sort of external 'enemy'. It would seem then, that this condition can be easily met in other nation-states, and must only be harnessed properly to provide the environment for stable nation-building.

(2) The presence and active mingling of social and political elites from each ethnic group can help establish a thick web of multi-ethnic civil society organizations that allow elites to unite in a common set of interests and goals, helping guide the process of inter-ethnic nation-building at lower social levels. Elite accommodation and consociation is a necessary process. The masses - pardon the loaded meaning of this word - need to be led and taught to believe in the value and 'natural-ness' of the multi-ethnic nation. If political and economic elites are themselves enlightened enough to accept the multi-ethnic nation, they will share in a common interest to see

\footnotetext{
${ }^{51}$ Steinberg, op. cit., 191.

52 Scott Taylor, "War on Iraq: Where America Went Wrong", October 26 2004. University of Kings College, Halifax, Canada.
} 
that it develops. In areas of ethnic strife, the consociation of elites would be a necessary step towards stable nation-building.

(3) A multi-ethnic nation can be constructed and thrive if the divergent groups that identify with it, will it to survive. Even a homogenous group will fail as a nation if members of the collection stop willing its continued existence. I am quite unsure as to how a national will develops, but perhaps familial education, a tolerant culture, and an innate respect (and even love) of liberty and self-respect have something to do with its creation. In any event, a national will that respects and even promotes the continued uniqueness of divergent groups, will likely lead to the creation of a stable multi-ethnic nation. It is likely, then, that once the cognitive setting of the group turns towards toleration and cherishing non-primordial bonds, nations and states will rise.

But then again, perhaps I am simply a little naïve and modestly idealistic... 


\section{Works Cited}

Ernst, Fritz. 1951. European Switzerland. Zurich: Fretz \& Wasmuth Limited,.

Gillett, Nicholas. 1989. The Swiss Constitution: Can it be Exported? Bristol: YES Publications,

Halbrook, Stephen P. 1998. Target Switzerland: Swiss Armed Neutrality in World War II. New York: Sarpedon..

Kaplan, Robert D. 2000. The Coming Anarchy: Shattering the Dreams of the Post Cold War. New York: Vintage Books.

Katzenstein, Peter J. 1984. Corporatism and Change: Austria, Switzerland, and the Politics of Industry. Ithaca: Cornell University Press.

Kerr, Henry H. Jr. 1974. Switzerland: Social Cleavages and Partisan Conflict. London: Sage Publications.

Kohn, Hans.1956. Nationalism and Liberty: The Swiss Example. London: Ruskin House.

McRae, Kenneth D. 1983. Conflict and Compromise in Multilingual Societies:

Switzerland. Waterloo, Ontario: Wilfrid Laurier University Press.

McRae, Kenneth D. 1964. Switzerland: Example of Cultural Coexistence. Toronto: Canadian Institute of International Affairs.

Miserez, Marc-Andre. 2004. "Debate heats up over Swiss Army System”, Swissinfo, August 5, 2004; <http://www.swissinfo.org>, Accessed August 28, 2006.

Poole, Ross. 1999. Nation and Identity, New York: Routledge.

Rappard, William E. 1948. Collective Security in Swiss Experience: 1291-1948. London: Bradford \& Dickens.

Renan, Ernst. 1990. “What is a nation?”, trans. Martin Thom, in Homi K. Bhabha (ed.), 
Nation and Narration. London: Routledge.

Schmid, Carol L. 2001. The Politics of Language: Conflict, Identity, and Cultural Pluralism in Comparative Perspective. New York: Oxford University Press.

Schmid, Carol L. 1981. Conflict and Consensus in Switzerland. Berkeley: University of California Press.

Siegfried, André. 1950. Switzerland: A Democratic Way of Life. London: Jonathan Cape.

Steinberg, Jonathan. 1976. Why Switzerland? New York: Cambridge University Press.

Taylor, Scott “War on Iraq: Where America Went Wrong”, Presentation, October 26 2004, Alumni Hall, University of Kings College, Halifax, Canada.

Wimmer, Andreas. 2002. Nationalist Exclusion and Ethnic conflict: Shadows of Modernity. Cambridge: Cambridge University Press,. 